Mediterranean Journal of Humanities mjh.akdeniz.edu.tr I/2, 2011, 237-253

\title{
Joseph Conrad'ın Gizli Ajan Romanındaki Winnie Verloc adlı Baş Kadın Karakter Üzerine Bir İnceleme
}

\author{
An Analysis of the Major Female Character Winnie Verloc in Joseph Conrad's \\ The Secret Agent
}

Mehmet Galip ZORBA*

Özet: 19. yüzyılın sonlarında ve 20. yüzyılın başında İngiliz edebiyatına pek çok eser kazandıran Polonya asıllı İngiliz yazar Joseph Conrad eserlerinde çoğunlukla sömürgecilik ve emperyalizm ile birlikte bunların ortaya çıkardığı olumsuzlukları kaleme almıştır. J. Conrad'ın eserlerindeki başkarakterler genellikle erkektir. Gizli Ajan romanı hem politik içerikli konusuyla hem de başkarakterinin bir kadın olması özelliğiyle Conrad'ın diğer romanlarından ilk bakışta hemen ayrılır. Romanın bir diğer özelliği de Viktorya Dönemi’nde kadının toplumdaki yerini çok çarpıcı bir şekilde ortaya koymasıdır. Gizli Ajan romanın içerik ve yaratılan karakterler açısından farklı oluşu romanı incelemeye değer bir eser kılmıştır. Bu çalışmanın amacı, Conrad'ın yarattığı karmaşık ve derin bir kadın başkarakter olan Winnie Verloc'u incelemektir.

Anahtar sözcükler: Joseph Conrad, Gizli Ajan, karakter incelemesi, Viktorya Dönemi

Abstract: British writer of Polish origin Joseph Conrad, who wrote many works of fiction in English between the end of the $19^{\text {th }}$ century and the beginning of the $20^{\text {th }}$ century mainly deals with colonialism, imperialism, and the problems resulting from them in his works. Besides, the main characters in his works are generally male. From this point of view, The Secret Agent, differs from his other works in terms of both its political topic and its main female character. Moreover, the other characteristic of the work is that it strikingly depicts the place of women in the late Victorian Age. Therefore both, The Secret Agent, and the main female character are well worth analysing. The aim of the study is to analyse Winnie Verloc, who has a complicated and deep character.

Keywords: Joseph Conrad, The Secret Agent, character analysis, Victorian Age

Joseph Conrad 19. yüzyılın sonlarında ve 20. yüzyılın başlarında İngiliz edebiyatına öykü, roman ve oyun türünde pek çok eser kazandırmıştır. Genellikle sömürgecilik ve emperyalizm üzerine yazan Conrad'ın eserlerinde deniz ve denizde geçen maceralar önemli yer tutar. Ayrıca birçok eserinde erkek karakterleri psikolojik ve epik ikilemler içinde sergilerken, kadın karakterleri ise, başkarakterleri ya destekleyici ya da daha alt konumlara indirgemiştir (Wheatley, 2001). Gizli Ajan romanı ise, işlenilen konu, hikâyenin geçtiği mekân ve de başkarakterinin kadın olmasyla Conrad'in diğer romanlarından ayrilır.

Conrad'ın, romanlarında kronolojiyi bozan, anlamı belirsizleştiren, bilinçsiz dürtüleri açığa vuran, medeniyetle barbarlık arasındaki sınırları silen, bilimsel ve ahlaksal kesinliklere temelden kuşku uyandıran anlatım teknikleri kullanması ve romanlarındaki karakterlerinde görülen " $y a-$ bancılaşma" anlatımını modernleştiren önemli unsurlardandır. Ayrıca en az Thomas Hardy kadar

\footnotetext{
* Arş. Gör., Akdeniz Üniversitesi, Eğitim Fakültesi, Yabancı Diller Eğitimi Bölümü, galipzorba@hotmail.com
} 
karamsar olmasına rağmen ondan farklı olarak karamsarlığını çok ince yollarla gizlemiştir eserlerinde. Bunların dışında da Conrad'ın romanlarındaki karakterler, özellikle de Gizli Ajan romanındaki profesör karakteri, Dickens romanlarındaki karakterlerle benzerlikler taşırlar (Karl, 1997). Bunun yanında Conrad, gelişen roman türüne gittikçe artan varoluşçu bir bakış açısı getirmiştir. Yarattı̆̆ karakterler kendilerini düşünsel boyutta sorgular ve insanın varoluş amacını bulmaya çalışırlar. Conrad'ın pek çok eserinde vurgulamak istediği, insanoğlunun anlaşılmazlığı ve duyarsızlığıdır (Bala, 1990).

1907 yılında yayınlanan Gizli Ajan romanı Conrad'ın birçok romanından farklı olarak denizde ya da yabancı ülkelerde değil; Londra' da geçmektedir. Conrad romanını "basit bir hikâye" olarak tanımlasa da bu basitlik romanın sadece yüzeyinde kalır (Karl, 1997). Londra'da yaşayan Adolf Verloc adlı bir casusun ve karısı Winnie Verloc'un öyküsünü anlatan roman anarşizm, casusluk ve terörizm konularını ele alır. Romanda Verloc Greenwich Gözlemevi'ne başarısız bir bombalı saldırı planlamıştır. Aslında Conrad bu öyküyü gerçek hayattan esinlenerek yazmıştır. Martial Bourdin adında bir Fransız 1894 yılında gerçekten de Greenwich Gözlemevi’ne bombalı bir saldırı yapmak isterken bombanın zamansız patlaması sonucu ölmüştür. Conrad Gizli Ajan romanına 1920 yılında yazdığı önsözde bir arkadaşının ölen bombacıyla ilgili söylediklerini şöyle aktarmıştır: "Ah, o adam yarım akıllıydl, o olayın ardından ablası intihar etti” (Conrad, 2006, $\mathrm{X})$. Zaten romanda da bombayı taşıyan Verloc'un kayınbiraderi Stevie gerçek hayatta da zekâ özürlüdür ve bombayı taşırken ayağının bir ağaç köküne takılması sonucu düşer. Bombanın erken patlamasına neden olup parçalanarak can verir. Canı kadar sevdiği küçük kardeşinin bu şekilde ölmesine dayanamayan ablası Bayan Verloc bir köprünün üzerinden atlayarak intihar eder.

Hem gerçek hikâyeden hem de Conrad'ın önsözünden anlaşılacağı gibi Gizli Ajan aslında Adolf Verloc'un değil, karısı Winnie Verloc ve kardeşi Stevie'nin öyküsüdür. Zaten Conrad da önsözünün son cümlesinde buna çok açık bir şekilde değinerek bu hikâyenin Winnie Verloc'un hikâyesi olduğunu belirtir.
“Ama yine de Winnie Verloc'un öyküsünü son derece perişan, delilik ve umutsuzlukla dolu anarşist sonuna dek anlatmakla ve onu burada dile getirdiğim gibi anlatmakla, insanoğlunun duyguların gereksiz yere incit- mek gibi bir niyetim olmadı̆̆ını belirteceğim” (Conrad, 2006, VX).

Conrad Gizli Ajan aracılığıyla Viktorya Dönemi’nde kadının toplum içerisindeki yerini çarpıcı bir şekilde göstermektedir. Eserin başkarakterinin kadın olması ve bu durumun yazarın diğer eserlerinden farklı bir karakter yaratımını içermesi Gizli Ajan romanını incelemeye değer kılmaktadır. Bu çalışmanın amacı da, Conrad'ın yarattığı karmaşık ve derin bir kadın başkarakter olan Winnie Verloc'u incelemektir. Viktorya Dönemi’nde kadının toplumdaki yeri hakkında genel bir bilgilendirme Winnie Verloc karakterini anlamakta yararlı olacaktır.

\section{Viktorya Dönemi'nde Kadının Toplumdaki Yeri}

Kraliçe Viktorya'nın (1837-1901 yılları arasında) tam 64 yıl İngiltere'nin başında kaldığı dönem Viktorya Dönemi olarak adlandırılır. Viktorya Dönemi'nde İngiltere'de sanayileşme ve makineleşme alanlarında büyük bir gelişme yaşanmıştır. Bunların dışında dünyanın pek çok yerinde savaşlar ve bu savaşların sonucunda yeni topraklar kazanan İngiltere Christopher North'un deyimiyle "topraklarında güneşin batmadĭ̆g" bir imparatorluk haline gelmiş ve oldukça zenginleşmiştir. Viktorya Dönemi siyasal alandaki olayların yanı sıra dönemin insanlarının ve toplumunun özellikleri açısından da kendine özgü bir yere sahiptir.

Gizli Ajan her ne kadar Edward Devri'nde kaleme alındıysa da romanın öyküsü Kraliçe Viktorya'nın başta olduğu 1886 yılında geçer. Conrad romanında bu tarihi açıkça belirtmese de bunu anlamamızı sağlayan iki önemli unsur vardır. Birincisi, Greenwich Gözlemevi’ne Martial 
Bourdin isimli şahsın başarısızlıkla sonuçlanan saldırısı 1886 yılında olmuştur. Conrad, romanını bu hikâyenin üzerine yazdığı için romanın zamanının bu yıl olması doğaldır. Assı önemli unsur ise, romanın sonunda Winnie Verloc'un evlilik yüzüğünün içinde evlendiği tarih olan 24 Haziran 1879 tarihinin kazılı olmasıdır. Winnie'nin Bay Verloc ile olan evliliği de yedi yıl sürdüğü için karşımıza yine 1886 yılı çıkar.

İngiltere siyasi ve ekonomik alanda her ne kadar başarılı olduysa da aynı gelişme ve iyileşme sosyal yaşama yansımamıştır. Ülkede birçok fabrika açıldığı için bu fabrikalarda çalışan işçilerin oluşturduğu bir işçi sınıfı doğmuştur. Zaten Viktorya Dönemi'nin sosyal alandaki en büyük sıkıntılarının başında işçi sınıfının yaşam ve çalışma koşullarının son derece kötü olması gelmektedir; çünkü işçiler saatlerce ara vermeden, yiyip içmeden, çok düşük ücretlerle çalışmak zorunda kalmışlardır. Erkeklerin yanı sıra kadınlar ve hatta çocuklar bile çok ağır şartlarda çalıştırılmışlardır (Auerbach, 2010; Urgan, 2004).

İngiltere'nin sanayileşmede gösterdiği gelişme çarpık kentleşmeye ve kırsal kesimden sanayi şehirlerine büyük oranlarda göçe neden olmuştur neden olmuştur. Bu yüzden kentlerde oturan hem işçiler hem de paralı sınıftan insanlar hızlı ve plansız gelişen bir çevrede çirkin eşyalar ile çirkin evlerde oturmaktaydılar (Urgan, 2004).

Viktorya Dönemi'nde kadının toplum içindeki yeri günümüzle kıyaslandığında çok gerilerdedir. Zaten Viktorya Dönemi'nin sonu ve Edward Dönemi'nin başlarında İngiltere'de iş̧̧i sınıfı sorunun yanı sıra bir diğer önemli konu da "kadın hakları meselesi"ydi (Thomas, 2002). Bu dönemde kadınlara yasalar önünde bir takım haklar verilse de, kadınların çektikleri sıkıntılar ve karşılaştıkları sorunlar çok da azalmamıştır. Viktorya Dönemi’nde oy kullanma hakkı, eğitim hakkı, miras hakkı ve çalışma hakları konusunda çok önemli gelişmelerin temelleri atılmıştır (Thomas, 2002).

Alt tabakadan insanlara siyasal ve yasal açıdan birçok hakkın verilmeye başladığı bu dönemde kadınlara oy kullanma hakkı verilmemiştir. Kadınlar bu hakkı ancak 1918 yılında elde edebilmişlerdir. 1870 yılında çıkan ve 1908 yılına kadar çeşitli düzenlemelerle geliştirilen evli kadınlara mülkiyet sahibi olma hakkını tanıyan yasa çıkmadan önce, evli kadınlar hiçbir şekilde mülkiyet sahibi olamıorlardı (Urgan, 2004).

Boşanmada ise erkekler eşleri zina gerekçesiyle boşayabiliyorken, kadınların eşlerinden boşanabilmeleri için zinanın yanında eşlerinin çok eşlilik, ensest ilişki ya da zulüm gibi suçlar işlemesi gerekiyordu. Ancak boşanma maddi açıdan çok yük getirdiği için sadece zengin kesimde görülebiliyordu (Ford, 2006).

Eğitim alanında da sınırlı hakları olan kadınlar üniversite eğitiminde büyük sıkıntılar çekiyorlardı. İngiltere'deki üniversitelerin çoğu onlara kapalıydı; ancak Viktorya Dönemi'nin sonunda üniversitelerin kapıları kadınlara açıldı (Auerbach, 2010; Bush, 2005). Yoksul işçi sınıfı kadınları çok ağır şartlar altında düşük ücretlerle uzun saatler boyunca fabrikalarda çalışmak zorundaydılar. İngiltere'nin kömür ve yakıt ihtiyacından dolayı maden işçilerine olan talep artınca kadınlara yeni bir iş alanı doğmuş oldu.

Viktorya Dönemi’nin en önemli sorunları arasında yer alan fuhuş, başka seçeneği olmayan kadınlar için adeta bir iş kolu haline gelmişti. Çalışma şartlarının kötülüğü ve kadınlara uygun yeterli oranda iş alanlarının olmaması kadınları fuhuşa yöneltmiştir. Aslında bu durum Viktorya Dönemi'nin tutuculuğuyla büyük bir tezatlık göstermektedir. Çünkü bu dönem cinselliğin tabu olduğu, İngiliz halkının ahlak ve toplum düzeni açısından Kraliçe Viktorya ve eşi Prens Albert'i örnek aldığı bir dönemdir. Kentlerde açlıktan ölmemek için bedenlerini satan pek çok kadına rastlamak mümkündür (Urgan, 2004). Fuhuşu ilk başlarda önemsemeyen İngilizler, fuhuşun yaygınlaşması sonucu ortaya çıkan hastalıkların farkına varınca bunun büyük bir sorun olduğunu anlamışlar ve 1864 yılında cinsel yolla bulaşan hastalıkları önlemek ve hayat kadınlarını kontrol 
altına alabilmek için bir yasa çıkartmışlardır. Ancak bu durumda da bir çifte standart hemen göze çarpmaktadır. Zira yasaya göre sadece hayat kadınlarının belli aralıklarla muayene edilmesi gerekmektedir. Ancak yasa onlarla ilişkiye giren erkekleri kapsamadığı için, bu erkeklere hiçbir tıbbi muayene yapılmamıştır (Sikorska, 2007).

Viktorya Dönemi’nde evlilikler ise, sevgi üzerine değil; sınıf atlama, karşılıklı çıkar ilişkileri veya gösteriş için yapılırdı. Sevgiden tamamıyla yoksun gerçeleştirilmekte olan evlilik bağı toplumda kutsal sayılmaktaydı (Urgan, 2004). Hem kutsal sayıldığı için hem de toplumun ve dinin baskısı altında tutulduğu için, bu dönemde evlilik kurumu yasaların yıkılmasına çok güç izin verdiği bir kurumdur (Urgan, 2004). Evlilik her sınıftan kadın için bir kurtuluş ya da bir sigorta olduğu için, o dönemde her kadının nihai amacı iyi bir evlilik yapmaktı. Ancak o dönemde nüfusta kadınların sayısının erkeklerden fazla olması nedeniyle evlenemeyen birçok kadın vardı. Bu durum yoksul kesimlerdeki kadınları fuhuşa yönlendirmekteydi. Orta sınıftan gelen ve belirli bir eğitim düzeyine sahip ama evlenememiş kadınlar ise, ya mürebbiyelik yapıyorlardı ya da son çare olarak göç ediyorlard1. Ancak, o dönemde mürebbiyelik, güvencesi olmayan, düşük ücretli ve hizmetkârlar ile aile üyeleri arasında belirli bir konuma sahip olmayan bir meslekti. Ayrıca mürebbiyelik, çalışanları da günün büyük bir kısmını evde geçirmeye zorunlu bırakıyordu.

Özetle, toplumda ve yasalar önünde çok fazla hakka sahip olmayan kadınların tek kurtuluş yolu iyi bir evlilik yapabilmekti. Çünkü kadınların çalışabileceği iş alanları hem çok kısıtlıydı hem de çalışma koşulları çok ağırdı. Çalışmanın ya da evlenmenin dışındaki tek yol ise fuhuştu. Viktorya Dönemi'ndeki sevgiden yoksun, çıkar ilişkilerine dayanan ve güvence için yapılan evliliklerin nedeni İngiltere'nin kadınlara sunduğu son derece kısıtlı imkânlardı (Urgan, 2004). Evli kadınlar da toplum tarafından "anne”, "ev kadını” ve "kocalarının cinsel ihtiyaçlarını gideren nesneler" olarak görülüyorlardı (Thomas, 2002). Ülkenin en tepesinde bir kadın varken bu dönemde kadınların, ikinci sınıf vatandaş muamelesi görerek pek çok haktan mahrum bırakılmaları ve evlilik, çok ağır şartlar altında ölümüne çalışmak ya da fuhuş üçgeni içerisinde sıkışıp kalmaları İngiliz toplumu için büyük bir tezat oluşturmaktaydı.

\section{Baş Kadın Karakter Winnie Verloc'un Bir İncelemesi}

Conrad'ın bu eserlerindeki asıl amacı kadının toplumdaki yerini irdelemek ya da eleştirmek değildir. Conrad eserlerinde çoğunlukla emperyalizmin ve sömürgeciliğin eleştirmiş ve bunların yıkıcı sonuçlarını göstermeye çalışmıştır. Gizli Ajan romanında ise, diğer eserlerinden farklı olarak casusluk, anarşist eylemler ve terörizm ilk planda göze çarpan unsurlardır. Ancak Conrad'ın asıl amac1, kriz anlarında insan ruhunu denemektir (Watts, 1994). Zaten romanda yaratılan anarşi ve toplumsal kargaşa da romanı klasik bir polisiye hikâye olmaktan çıkarır (Harrington, 1999).

Gizli Ajan, giriş kısmında da belirtildiği gibi, Adolf Verloc'un değil, Winnie Verloc'un hikâyesidir. Zaten Conrad'ın esinlendiği gerçek olayda da bombalı saldırgan ve onun intihar eden ablası vardır. Conrad, Stevie ve ablası Winnie Verloc'un dışındaki karakterleri hikâyeyi zenginleştirmek için yaratmıştır. Romana bakıldığında da Bay Verloc karakteri ile Winnie Verloc karakteri arasında ters bir orantı vardır. Bay Verloc roman ilerledikçe arka plana doğru gerilerken romanın son birkaç bölümünde ise Winnie başrole geçer adeta. Winnie Verloc'un hikâyesi, Bay Verloc'un bunaltıcı tavırlarının ve onun bilinçsiz anarşist arkadaşlarının hikâyeleriyle Winnie'nin intiharına kadar adım adım özenle işlenmektedir (Karl, 1997).

Conrad'ın Gizli Ajan'ın esas hikâyesi olarak belirttiği Winnie Verloc karakterini fiziksel özellikleri, evliliği, Ossipon karakteriyle olan ilişkisi, anne ve kardeşi Stevie ile olan ilişkileri açısından incelemek onun ne kadar karmaşık bir karakter olduğunu göstermeye yardımcı olacaktır. Hikâyenin özünü oluşturan Winnie Verloc'un fiziksel özellikleri ve dış görünüşünü yansıtan tasvirlerin sayısı sınırlıdır. Romanlarında diğer karakterlerin de fiziksel özelliklerine çok fazla değinmeyen Conrad, bu kuralını sadece Adolf Verloc için bozmuştur; çünkü diğer karakterlerin 
fiziksel özelliklerine bir ya da iki kez ve oldukça kısa bir şekilde değinen Conrad, Bay Verloc'un şişmanlığından, bıyığından ve tıraşlı, pürüzsüz, tombul yüzünden birkaç yerde bahseder.

Conrad (2006, 19), genç bir kadın olan Winnie için “Winnie Verloc iri gögüslü, korse giyen, geniş kalçall, genç bir kadındı. Saçları gayet düzgündü. Kocası gibi sabit bakışlı olan kadın, tezgâhın oluşturduğu siperin altında kayıtsızlık halini korurdu”der. Bunların dışında, Conrad Winnie'nin siyah saçlarından, cazibesinden ve vücut hatlarından hayranlıkla bahseder.

“Dulun övündüğ̈̈ Fransı kökeninin belirtileri Winnie'de de göze çar-
pardı. Bu belirtiler klzın parlak siyah saçlarının olağanüstü düzgün ve
şı tasarımından görünüyordu. Winnie'nin başka cazibeleri de vardı:
Gençliği, dolgun ve yuvarlak hatları, beyaz teni; hiçbir zaman, kiracı ta-
rafindan şevkle, kendisi tarafindansa buna eşdeğer bir sevimlilikle sür-
dürülecek bir konuşmayı engelleyecek kadar ileri gitmeyen o sonsuz ka-
yıtsızlığının tahrik ediciliğiydi” (Conrad, 2006, 20).

Winnie Verloc'un evliliğini, kocasıyla olan ilişkisini ve bu evliliğin temelinde yatanları derinlemesine incelemek Winnie Verloc karakterini iyi anlayabilmek için çok önemlidir. Bunun sebebi de Winnie Verloc'un yaptığı veya söylediği her şeyle doğrudan ya da dolaylı bir biçimde evliliğinin ve kocasıyla olan ilişkisinin bir bağlantısının olmasıdır. Verloc çiftinin evlilikleri dışarıdan bakıldığında, gayet normal ve sıradan bir evlilik gibi görünür. Romanda Bay Verloc'un işlettiği ve "karanlık malların" satıldığı dükkânın bulunduğu sokakla Verloc çiftinin evlilikleri bezerlikler göstermektedir. Brett Sokağ 1 Verloc çiftinin evliliklerindeki ve ev yaşamlarındaki kasvetin ve yalnızlığın bir göstergesidir adeta (Bernstein, 2003). Conrad, "güneşin nadiren de $\breve{g}$ diği”" (Conrad, 2006, 52) Brett Sokağı'nı oldukça iç karatıcı bir şekilde yansıtır. "Gazeteci çocuklar Brett sokağına hiç girmezdi. Onların para kazanacakları bir sokak değildi burası. Ve bağırtılarının kalabalık caddeler boyu dolaşan yankıları dükkânın eşiğine varmadan kirli tuğla duvarların arasında sönüp gitmişti” (Conrad, 2006, 221). Kısacası Brett Sokağı'nın sesten ve 1şıktan mahrum oluşu aslında Verloc çiftinin evliliklerinde de karanlıkta kalan yerlerin olduğuna bir işarettir (Bernstein, 2003). Dolayısıyla bu bile Verloc Çiftinin evliliklerinin çok sıradan bir evlilik olmadığının bir göstergesidir. Winnie'nin evlilikteki rolüyle toplumun evlilikte kadınlara biçtiği rol aynıdır (Harrington, 2004).

Verloc çiftinin evliliklerinin sıradanlıktan uzak olmasının nedenlerinden birisi de Bay Verloc'un işidir aslında. Her ne kadar Brett Sokağı'ndaki küçük dükkânında belli belirsiz mallar satan bir esnaf gibi görünse de aslında bu göstermelik bir iştir. Bay Verloc gerçekte bir gizli ajandır ya da Conrad'ın deyimiyle bir "ajan provakötör"dür. Zaten Conrad daha ilk paragrafta "Bay Verloc bu sözde işine pek de önem vermiyordu" (Conrad, 2006, 17). diyerek, bu işin bir paravan olduğunun açıkça belirtir. Dükkânda satılan mallar da tıpkı Bay Verloc'un görünen kimliği gibi belirsizdir. Conrad, Bay Verloc'un dükkânını şöyle betimler:

"Vitrininde yarı çıplak, dans eden kızların resimleri vardl; kocakarı ilaçlarınınkine benzeyen kâğıtlara sarılmış, ne olduğu belirsiz paketler, çok ince kâğttan yapılmış, üzerine kalın siyah harflerle iki ve altı yazılı koyu sarı zarflar; bir ipe sanki kurutuluyormuş gibi asılmış birkaç tane çok eski Fransız mizah dergisi; soluk mavi Çin porseleninden bir kâse, karaağaçtan yapılmış bir mücevher kutusu, sabit mürekkep şişeleri ve kauçuk mühürler vardl; isimleri uygunsuzluk ima eden birkaç kitap; kötü baskıll, Meşale ya da Gong gibi-tahrik edici- başlıklar taşıyan müstehcen gazetelerin eski olduğu anlaşılan birkaç nüshası" (Conrad, 2006, 18).

Bunun yanı sıra, Conrad dükkânı "Bay Verloc'un karanlık mallar satmak olan işini yaptı̆̆ı, toplumu koruma hizmetini sürdürdüğü ve ailevi meziyetlerini yürüttüğü yer" olarak da tanımlar. Bay 
Verloc'un sözde işine, dükkânına, bu dükkânda satılan mallara ve de Brett Sokağı'na bakınca sıradan bir insan olmaktan çok uzakta duran bir adam çıkıyor karşımıza. Karısı Winnie Verloc ise ilk önce "karşılaştığı olayların iç yüzünü bilmezden gelmeyi prensip haline getirmiş" bir kadın olarak betimlense de romanın ilerleyen kısımlarında bu betimlemenin oldukça yüzeysel kaldığı görülür. Winnie kocasının esnaflık işinin göstermelik olduğunu bildiği halde bunu fazla kurcalamaz. Ama Bay Verloc'un gizli bir takım işler içinde olduğunu da bilir. Çünkü Bay Verloc günün birinde gerçek işini siyasi bir iş olduğunu söyler. Kadında olayların iç yüzünü merak etmediği için bunu çok fazla kurcalamaz.

Bay Verloc'un gerçek işi -dolayısıyla da gerçek kimliği- karısıyla olan iletişimini de olumsuz yönde etkiler. Bay Verloc Greenwich Gözlemevi'ne bombalı bir saldırı yapma emrini aldıktan sonra bu görevin verdiği baskıyla iyice içine kapanır. Zaten Bay Verloc konuşkan birisi değildir. Karısıyla hep belirli şeyler konuşur ya da Winnie'nin anlattığ şeyleri dinliyormuş gibi yapar. Örneğin, Bay Verloc bir akşam uyumak için yatak odasına çıkar. Ancak Winnie zekâ özürlü kardeşi Stevie'nin davranışlarıyla ilgili bir şeyler anlatmaya koyulur. Winnie konuşurken Bay Verloc aldığı görevin baskısından dolayı karısını dinlemez. "Bay Verloc'un gerginliği, karısının söylediklerinden bir anlam çıkarmasını olanaksız kılmıştı. Kadın çok kalın bir duvarın öte yanından konuşuyormuş gibiydi" (Conrad, 2006, 73).

Buna benzer bir şekilde annesinin 1srarla birkaç tanıdığını araya koyarak güç bela ayarladığı bakımevinde kalmak istemesine çok içerleyen Winnie, hem bu durumu, hem de Stevie'nin annesinin gidişinden dolayı çok zorluk çekeceğini yine yatak odasındayken Bay Verloc’a anlatır. Fakat adam da yine kadının söylediklerini önemsemez. Kadın bunları söylerken Bay Verloc çok başka şeyler düşünür. "Bay Verloc, hiç farkına varmadan kendi içinde yoğunlaşarak giysilerini çıkarmaya devam etti, uçsuz bucaksız ve hiç umut vermeyen bir çölün ıssızlığında soyunan bir adam gibi” (Conrad, 2006, 196).

Bay Verloc'un bu tutumunun aksine Winnie Verloc kocasına bağlı ve ailesine bağlı bir eş portresi çizer. Aralarındaki iletişim eksikliği ve mesafeden rahatız değildir. Bay Verloc da Winnie için benzer şeyler düşünür. "Karısını bir eşin sevilmesi gerektiği gibi seviyordu; yani evliliğe uygun bir biçimde sahip olduğu en birinci şeyi sever gibi” (Conrad, 2006, 197). Ancak bu noktada önemli bir ayrıntı vardır. Roman boyunca buna benzer şeyleri Winnie'nin söylediğine tanık olmayız. Üstelik Bay Verloc'tan evlenmeden önceki nazik ve kibar tavırlarını beklemez hale gelir artık, ona karşı bir saygı duyar sadece.

"Çekiciliğinden tümüyle emin olan Winnie, evlilik hayatlarının günlük
ilişkilerinde kocasının kendisiyle nazik bir tarzda konuşmasını ve kendi-
sine kibar bir tarzda davranmasını beklemezdi; bunlar olsa olsa gereksiz
ve çoktan eskimiş, muhtemelen hiçbir zaman tam anlamıyla yerine getiril-
meyen, bugün en üst çevrelerde bile bırakılmış ve onun sınıfinın standart-
larına daima yabancı tavırlardl. Kocasından nezaket beklemiyordu.
Winnie, kocasının ayrıcalıklarına sadakatli bir saygı duyardı” (Conrad,
2006, 208).

Alıntıdan da anlaşılacağı gibi Winnie için bu evlilik kardeşi, annesi ve kendisi için güvenli bir hayat temin etmekten öte bir anlam taşımaz ve bundan başka bir beklentisi de yoktur. Verloc çiftinin evliliklerindeki iletişim eksiliği ve Winnie'nin kocasının ne iş yaptığı üzerine çok fazla kafa yormaması, Stevie'nin ölümünden sonra Winnie'nin kocasını aslında hiç tanımadığını anlamamızı sağlar.

Bay Verloc, Greenwich Gözlemevi'ne yapacağı bombalı saldırı görevinde Winnie’nin özürlü kardeşi Stevie'yi kullanır. Çünkü oğlan Bay Verloc'a hem hayran olduğu için onun dediği her şeyi yapardı hem de Bay Verloc'tan çekindiği için söylemesini istemediği bir şeyi asla kimseye 
anlatmazdı. Bu özelliklerinden dolayı da Bay Verloc'un çok gizli görevi için biçilmiş kaftandır. Bay Verloc bombayı bir paketin içine koyar ve bu paketi Stevie'ye vererek ondan paketi söylediği yere götürmesini ister. Ancak Stevie bombayla birlikte koşarken ayağı ağaç köklerine takılır, düşer ve bombanın patlamasına neden olur. Ne taşıdığından habersiz olan Stevie paramparça olarak korkunç bir şeklide can verir.

Stevie zihinsel açıdan normal biri olmadığı için dışarıda sıklıkla yolunu kaybeder. Ablası Winnie de paltosun iç kısmına evin adresinin yazılı olduğu bir kumaş parçası diker. Patlamadan sonra Başmüfettiş Heat bu kumaş parçasını bulur ve bu kumaş parçasının üzerinde yazılı olan adrese gider. Kardeşinin ölüm haberini duyan Winnie bu haberi alınca yıkılır ve kardeşinin ölümünün kocasının yüzünden olduğunu anlar.

Stevie’nin ölümü Verloc çiftinin evliliklerini bitiren olaydır. Çünkü Winnie, annesi ve Stevie'nin rahat yaşaması için Bay Verloc'la evlenmiştir. Annesi bir bakım evine gittiği ve çocuk da ölüğü için artık bu evliliğin bir anlamı da kalmaz kadın için. Bu durum aslında Verloc çiftinin evliliklerinin tamamen Stevie'nin durumuna bağlı olduğunu, başka bir deyişle pamuk ipliğine bağlı olduğu gösterir. Bu açıdan bakıldığında aslında Winnie Bay Verloc'u değil; onun kardeşi ve annesi için sağladıklarını sever (Wheatley, 2001).

Bay Verloc, Stevie'nin ölümünün bir kaza olduğunu açıklamaya çalışsa da Winnie kocasının, kardeşini bilerek öldürdüğünü düşünür. "Bu adam o çocuğu öldürmek için götürdü. Çocuğu evinden alıp öldürmeye götürdü. Benden alıp öldürmeye götürdü!” diye düşünür (Conrad, 2006, 265). Oysa Bay Verloc'un böyle bir niyeti yoktur. Ayrıca aldığı bombalı saldırı görevi de insanları öldürmek için değil, sadece İngiliz hükümetine gözdağı vermek için bir binaya tenha bir vakitte saldırı yapmaktır.

Stevie'nin ölümü Verloc çiftinin birbirlerini gerçekten de hiç tanımadıklarının ve evliliklerinin çok yüzeysel olduğunun su yüzüne çıkmasına neden olur. Çünkü bu olayın hemen ardından vicdan azabı çeken Bay Verloc ile canı gibi sevdiği kardeşini kaybeden Winnie Verloc'un zihinlerinden çok farklı şeyler geçer ve her ikisi de karşı tarafın aklından geçen şeyleri tahmin bile edemez. Bay Verloc bir yandan kardeşinin ölümü ile sarsılan karısını teselli etmeye çalışırken bir yandan da iştahlı bir şekilde yemek yer. Karısına "Lütfen makul ol Winnie. Beni kaybetseydin ne olacaktı?” der. Karısıyla bunları konuşurken, aklından da hapis cezası kaçınılmaz olduğu için dükkâna ne olacağı geçer ve karısının bir an önce kendini toparlaması gerektiğini düşünür ve "Beni içeri tıktıklarında dükkâna o bakacak" der, kendi kendine (Conrad, 2006, 254). Bay Verloc hem kadın kendini iyi hissetsin diye, hem de suçluluk duygusundan dolayı mümkün olduğunca konuşmaya çalışır, Winnie'yle. Ancak yatak odasındaki konuşmaların aksine dinlemeyen taraf bu kez Winnie Verloc'tur. Yani diğer bir deyişle roller artık değişmiştir. Bu duruma da pek alışık olmayan Bay Verloc karısının kendisini anlamış olduğunu düşünür.

Oysa Bay Verloc çok yanılır, çünkü durum düşündüğünden çok farklıdır. Winnie kardeşinin ölümünden kocasını sorumlu tutmakla kalmaz, adamın bunun bilerek yaptığını düşünür. Bay Verloc ile evlenmesindeki en büyük etken de Stevie olduğu için artık bu evliliğin bittiğine karar verir. "Kadının orada, o mutfakta, o evde, o adamla kalmasına gerek yoktu -çünkü çocuk artık ebediyen gitmişti-" (Conrad, 2006, 269). Kendine karşı ilgili gibi görünen ama aslında vurdumduymaz tavırlar sergileyen Bay Verloc'un kardeşini bilerek öldürdüğünü düşünen ve bu evliliğin bittiğine karar veren Winnie, kanepede uzanmış yatan Bay Verloc'un yanına mutfaktan aldığı et bıçağıyla gider ve bıçağı Bay Verloc'un göğsüne saplar.

Bu vahşet sessiz, sakin, uysal bir mizacı olan, evine ve ailesine bağlı görünen Winnie Verloc gibi bir kadından beklenmeyecek bir harekettir. Kocasının neden olduğu şiddete ve vahşete, ay$\mathrm{n} 1$ şekilde şiddet ve vahşetle cevap verir (Sikorska, 2007). Conrad bu şiddet anını şöyle tasvir eder:

"Bayan Verloc, divanın yüksek yan tarafinın üzerinden aşan bu delici 
darbeye, hatırlanmayacak kadar eski çağlardan ve karanlık soyundan gelen bütün mirasın, mağara çağının basit vahşetini ve meyhane salonlarının dengesiz ve hirçın öfkesini katmıştı. Darbenin etkisiyle hafifçe yana dönen Bay Verloc, yani casus, kolunu bile kimildatamadan mirıltı gibi çıkan, itiraz etmek amaçlı bir "dur" sözcü̈g̈ülle can verdi” (Conrad, 2006, 281).

Verloc çiftinin dışarıdan sıradan gibi gözüken, ama gerçekte hiç de öyle olmayan evliliklerinin neden cinayet gibi şiddet ve vahşet içeren bir olayla sona erdiğini anlayabilmek için bu evliliğin hangi düşüncelerle, hangi nedenlerle ve hangi koşullarda yapıldığını bilmek gerekir. Viktorya Dönemi'nde yapılan evliliklerde karşılıklı sevgi ya da aşk önemli rol oynamamıştır. Ancak o dönemde yapılan her evlilik de tamamen çıkar amaçlı ve duygusuzca yapılmamıştır. Viktorya Dönemi evliliklerinde çıkar ilişkisiyle birlikte "anlayış" ve "duygudaşlık" önemli rol oynardı (Ablow, 2007). Diğer bir deyişle, sevgi ve aşk olmasa bile ortak duygular paylaşabilmek ya da ortak bir amaç sahibi olmak önem taşımaktadır. Verloc çiftinin evliliklerine bakıldığındaysa "duygudaşlık” ya da "anlayış" göremeyiz. Bay Verloc karısını kendince severken, Winnie kocasına karşı aynı duygulara sahip değildir. Bay Verloc, Stevie'nin ölümünden dolayı yıkılmış olan karısına, onu bu işe zorlayanlardan öç alma arzusundan ve ülkeden kaçma niyetinden neden vazgeçtiğini anlatırken, karısına “Çünkü seni çok seviyorum”der (Conrad, 2006, 267). Bay Verloc için karısı önemlidir:

“'Evet, Sir Ethelred,' dedi müdür yardımcisı uzatılan eli saygılı bir şekilde sılkarken, "gerçek bir eş ve gerçek, namuslu bir evlilik ilişkisi. Adam bana, 'Büyükelçilikteki görüşmemden sonra her şeyden vazgeçerdim, dükkânı satmaya çalışırdım ve bu ülkeyi terk ederdim,' dedi; ama karısının yurtdlşına gitmenin lafinın bile duymak istemediğini kesin olarak hissediyormuş. 'Namuslu bir evlilik bağının bundan daha karakteristik bir göstergesi olmaz,' diye devam etti kendi karısı da yurt dişına gitmenin lafinı bile duymayı reddeden Müdür Yardımcısı hafiften keyfi kaçmış bir edayla. 'Evet, gerçek bir eş'”' (Conrad, 2006, 239).

Hem içerden hem de dışarıdan bakıldığında Bay Verloc'un karısına verdiği kendince değer açıkça gözükür. Ancak Winnie Verloc için aynı şeyleri söyleyebilmek pek de mümkün değildir. Çünkü Winnie Verloc'un Bay Verloc'la evlenmekteki tek amacı zekâ özürlü kardeşine ve yaşlı annesine bir güvence sağlayabilmektir. Bu dönemde sevgisiz evlilikler çok yaygındır ve bu tür evlilikler kutsal sayılmaktadır (Urgan'dan aktaran Arıkan, 2009). Winnie, Bay Verloc'la evlenmeye o kadar ani bir şeklide karar vermiştir ki annesi bile buna çok şaşırır; çünkü Winnie aslında kasabın oğluyla görüşmektedir. Winnie'nin annesine göre kızının Bay Verloc'la olan evliliği:

“Aslında Winnie'nin Bay Verloc'la niçin evlendiğini hiç anlayamamıştı. Winnie için gayet akla uygun bir işti bu ve görünen o ki sonu gayet iyi çıkmıştı; ama kızı doğal olarak, yaşı kendine daha uygun birini bulmayı umut edebilirdi. Yan sokakta, Winnie'nin keyifle çıktı̆̆ belli olan bir genç vardl; kasabın tek oğluydu ve dükkânda babasina yardım diyordu. Oğlan babasına bağımliydl, doğru; fakat iş iyiydi ve çocuğun geleceği mükemmeldi. Oğlan birkaç kere klzı tiyatroya götürdü. Sonra kadın, tam, onların nişanlandiğı haberini duymaktan korkmaya başlamışken o koskocaman evde, başında bir de Stevie varken ne yapardı sonra) o iliş̧ki birdenbire bitiverdi ve Winnie gayet vurdumduymaz bir görünüşle hayatına devam etti. Fakat Bay Verloc tam zamanında ortaya çıkıp da birinci katın ön odasını tutunca genç kasap diye bir sorun kalmadı" (Conrad, 2006, 54). 
Alıntıdan anlaşılacağı üzere, Winnie'nin genç kasapla çok iyi ve adım adım evliliğe doğru gitmesi beklenen ilişkisi birden biter. Winnie, dışarıdan bakıldığında her ne kadar vurdumduymaz gibi görünmeye çalışsa da, genç kasabı asla unutmamıştır. Çünkü o genç kasabın hayali bile kendisini zaman zaman iyi hissetmesine neden olur.

\begin{abstract}
"Bu hayalde sicak bir Londra yazının nefesi ve merkezi figür olarak da en iyi pazar giysilerini giymiş, siyah saçlı başında hasır şapka, ağzında tahta pipo bulunan bir delikanlı vardl. Bu sevgi dolu ve hoş genç köpürerek akan yaşam nehrindeki yolculuk için harika bir yol arkadaşlydl; yalnız kayı̆̆ı çok küçüktü işte. Bu kayıkta, kürek çekecek bir yol arkadaşı için yer vardı da yolcular için oturacak yer yoktu. Bu delikanlı Belgravia konağının eşiğinden çıkıp gitsin diye gönderilirken, Winnie yaşlı gözlerini siliyordu. Bu genç bir kiracı değildi. Kiracı Bay Verloc'tu; tembel ve hep geç saatlerde dönen, sabahları yorganın altında mahmur bir halde şakalar yapan ama şiş göz kapaklarının arasından âşıkça bakan ve cebi her zaman paralı biri. Bu adamın hayatının durgun nehri köpürmezdi; gizli yerlerden akardı. Fakat teknesi geniş bir kotraya benziyordu ve yüce gönüllü suskunluğuyla, doğal olarak yolcuların varlı̆̆ını kabul ediyor$d u$ ” (Conrad, 2006, 261-262).
\end{abstract}

Alıntıdan da ortaya çıkıyor ki, genç kasap Winnie Verloc'un aklından hiçbir zaman çıkmamıştır. Annesinin düşüncelerinin aksine, Winnie o genç kasabı çok sevmiş ve onunla evlenmeyi düşünmüştür. Ancak Stevie ve annesiyle birlikte genç kasapla yaşayamayacağı için, sevgisinden vazgeçip, Bay Verloc'la evlenmiştir; çünkü Bay Verloc, gizli kapaklı işlerle uğraşmasına rağmen, kardeşi ve annesi için bir kurtuluş yoludur ve Winnie'nin başka bir seçeneği yoktur. Kocasını öldürdükten sonra kaçmak için yardım istediği Ossipon'a kasabın oğlu ve Bay Verloc'la olan durumunu şöyle anlatır:

"'O zamanlar sevdiğim erkek oydu'. Diye devam etti Bayan Verloc, 'sanırım o da bunu benim gözlerimde görebilirdi. Haftada yirmi beş şilin ve babası, sakat anasıly geri zekâlı deli kardeşi eline bakan bir kızla evlenmek gibi bir aptallı yaparsa onu dükkândan kovmakla tehdit etti. Fakat o yine de benden ayrilamadı ve sonunda ben bir akşam onun suratına kapıyı çarpacak cesareti buldum. Bunu yapmak zorundaydım. Onu çok seviyordum. Haftada yirmi beş şilin! Bir de diğer adam vardı; iyi bir kiracı. Bir kiz ne yapabilir? Sokaklara mı düssseydim? Adam kibar görünüyordu. Beni de istiyordu. Annemi ve o zavall çocuğu ne yapacaktım? Ha? Evet dedim. Adam iyi huylu görünüyordu, cömertti, parası vardl, sessiz sakindi” (Conrad, 2006, 295).

Winnie'yle genç kasabın ilişkilerinin bitmesinin nedenleri arasında sadece sakat annesi ve zekâ özürlü kardeşi değil, aynı zamanda da genç kasabın kazandığı paranın geçinmek için yeterli olmamasıdır. Winnie'nin evliliğinin temelinde ailesine rahat ve güvenli bir yaşam sağlayabilme çabası yatar. Diğer bir değişle, Viktorya Dönemi evliliklerinin temel özelliklerini taşıyan bu evlilik, çıkar ilişkisine dayalı bir evliliktir. Bay Verloc'un Winnie'yi sevdiği, Winnie'nin de kocasını hiç sevmediği göz önüne alınırsa bunun bir maddi sömürü olduğu da düşünülebilir. Çünkü Winnie'nin evliliğindeki temel nedenlerden biri de, Bay Verloc'un parasının olmasıdır. Yani Verloc çiftinin sözde saygıdeğer ve namuslu evliliklerini oluşturan maddi sömürüdür (Lutz, 2008).

Çıkar ve sömürü üzerine kurulan bu evlilik adeta karşılıklı yapılmış "ticari bir anlaşma" gibidir (Lutz, 2008). Bu anlaşmada Bay Verloc'a düşen görev iyi, cömert ve kibar eş olup, karısına, karısının kardeşine ve annesine güvenli bir sığınak olmakken, Winnie’ye düşen görev 
ise iyi, namuslu bir eşin yapması gerekenleri -kocasıyla ilgilenmek, yemek, temizlik ve cinsel tatmin gibi- yapmaktır. Arıkan'ın (2009) Urgan'dan aktardığı gibi Viktorya Dönemi’nde, ailevi değerlerle saygıdeğer olma merakı ve bunun sonucunda ortaya çıkan ikiyüzlülük oldukça sık rastlanan bir durumdur. Bu anlaşmanın Winnie'ye getirdikleri kadar, Winnie'den götürdüklerine de bakmak gerekir. Winnie Verloc sakat annesi ve zekâ özürlü kardeşi için sevdiği adamdan vazgeçer. Ancak Winnie'nin vazgeçtiği şeyler bunlarla da kalmaz. Dükkân, kocasının paravan olarak kullandığı bir yerdir. Aslında Bay Verloc gizli bir ajandır. Bu nedenle de dükkânda fazla kalmaz. Hem dükkânla hem de evle Winnie ilgilenir. Bu da Winnie’yi adeta eve hapseder. Genellikle Viktorya Dönemi’nde orta ya da alt sınıftaki kadınlar eğer çalışmıyorlarsa evlendikten sonra eve mahkûm olurlardı (Tabili, 2002). Romanda da Winnie, annesini bakım evine bırakmak için kendi isteği dışında dışarı çıkar. Kendi isteğiyle dışarı çıktığı tek an kocasını öldürdükten sonraki andır, ancak orada da dışarı çıkmakta tereddütler yaşar. Winnie Verloc'a göre "her adım büyük bir iradeyle atılan ve sanki arkası gelmeyecek büyük bir çabayı gerektiriyordu" (Conrad, 2006, 289). Eve hapsolmanın dışında Winnie Verloc, hem dükkânla hem de evle ilgilenen bir işçi ve sevgisiz yapılan bir evlilikten dolayı cinsel bir nesne haline gelir (Lutz, 2008). Diğer bir deyişle Winnie, Bay Verloc'la evlenerek kendi mutluluğundan vazgeçmiş, Stevie ve annesinin güvenliği için esaret altında sevmediği bir adamın yatağına girmek zorunda kalmıştır (Lutz, 2008). Ancak Urgan'a göre bireysel koşullardan aptalcasına memnun olmak Viktorya Dönemi'nin özellikleri arasında yer alır (akt. Arıkan, 2009). Eserlerinde soyutlamalara çokça yer veren Conrad, yalnızca bireyleri soyutlamakla kalmaz, onun soyutlamaları toplum, özellikle de evlilik içindeki gizli soyutlanmadır ve Conrad'ın eserlerinde pek az evlilik mutludur (Parlakyıldız, 2007).

Verloc çiftinin evliliği sadece tek taraflı sömürü üzerine kurulu değildir. Karısını seven ve kirli işlerinin içine pek sokmak istemeyen Bay Verloc da, karısının kardeşi Stevie'yi sömürür. Ona verilen bombalı saldırı görevini kendisi yapması gerekirken, onun sözünden çıkmaması, ona hayran olması ve iyi sir saklaması nedeniyle Stevie'ye yaptırmaya karar verir. Yani Stevie'yi bir "maşa" ya da "taşeron" olarak kullanır.

Stevie’nin ölümü Verloc çiftinin evlilikleri için dönüm noktasıdır. Bay Verloc’un “kotrasındaki yolculardan” geriye kalan tek kişi Winnie'dir. Ancak kardeşi kocası yüzünden öldüğü için de Winnie Verloc artık ticari bir anlaşmaya benzeyen ilişkilerini bitirmeye karar vererek Bay Verloc'un "geniş kotrasından" inmeye karar verir. "Kadının orada o mutfakta, o evde, o adamla kalmasına gerek yoktu -çünkü çocuk artık sonsuza kadar gitmişti. Buna hiç gerek yoktu. Ve bunun üzerine Bayan Verloc yaydan firlamışçasına ayağa kalktı" (Conrad, 2006, 269-270). Stevie'nin ölümü üzerine evlilik anlaşması sona erer: "Tam o anda Bayan Verloc, kendini dünyayla bütün bağlarından kurtulmuş görmeye başladı. Kadın, özgürlügünü kazanmıştı. Onun var oluşla yaptığ ve şurada duran adam tarafindan temsil edilen anlaşma bitmişti”' (Conrad, 2006, 270). Winnie'nin Bay Verloc'a karşı duyduğu saygı dışında tek gerçek duygu güven duygusudur. Zaten bunu da kocasına "Sana güvenmeseydim seninle evlenmezdim" (Conrad, 2006, 210) diyerek açıkça söyler. Ancak Stevie’nin ölümüyle Bay Verloc’a karşı duyduğu saygıyı da güveni de yitirir.

Evliliğini kafasında bitirmiş olan Winnie'nin kocasını öldürmesinin tek nedeni, Bay Verloc'un Stevie'yi öldürmek için parka götürdüğünü düşünmesi değildir. Winnie kocasının kardeşi Stevie ile daha fazla vakit geçirmesini istemiştir. Kocasına da Stevie'yi kullanma fikrini istemeden de olsa kendisi vermiştir. Kocasına "Bu çocuğa her istediğini yaptırabilirsin Adolf. O senin için ateşe bile atlar" diyerek, Bay Verloc'a istemeden Stevie'yi bombalı saldırı eyleminde kullanması için fikir verir. Ayrıca Bay Verloc saldırıyı gerçekleştirmeyi planladığı gün dışarı çıkarken "Keşke şu çocuğu da yanında götürsen, Adolf'der. Winnie'yi cinayete iten diğer neden ise Bay Verloc ile Stevie dışarı çıkarken, Winnie'nin arkalarından bakıp ve aynı paltoyu giydiklerini görünce onları babayla oğla benzetir: 


\begin{abstract}
“'Sanki babayla oğul gibi,' dedi kendi kendine. Ayrıca Bay Verloc'un zavallı Stevie'nin hayatında gördüğ̈̈ kadartyla bir babadan farksız olduğunu düşündü. Bunun kendisinin sayesinde olduğunu da düşündü. Ve yıllar önce gösterdiği kararlllıktan ötürü sevindi; huzurlu bir gurur duydu. Bunun için biraz acı çekmesi ve hatta birçok gözyaşı dökmesi gerekmişti” (Conrad, 2006, 204).
\end{abstract}

Winnie Verloc'un tamamen iyi niyetle kocasının ve Stevie'yle vakit geçirmesini istemesinin altında başka nedenler yattığını düşününen Bay Verloc, bu durumu sanki kötü bir niyetle ve kasitlı yapılmış bir olay olarak görür ve şöyle der:
"Ben hepimizi bu dertten kurtarmanın sıkıntıslyla düşünüp dururken o çocuğu boyuna benim önüme süren sensin. Ne halt ettin Tanrl aşkına? Görende bunu amaçlı bir şekilde yaptığını sanacak. Ve senin böyle bir amacın olup olmadığını biliyorsam gözüm çıksın” (Conrad, 2006, 76).

Bununla da yetinmeyen Bay Verloc "Onu benim öldürdüğ̈̈mü iddia edecek olursan, o zaman sen de benim kadar öldürdün” (Conrad, 2006, 276) diyerek, Stevie’nin ölümünden Winnie’yi suçlar. Zaten çok sevdiği kardeşinin ölümünden tamamen Bay Verloc'u suçlu tutan Winnie'nin aklına bir de kardeşinin patlamadan parçalanan bedeninin ancak bir kürek yardımıyla toplanabildiği gelince, bir anlık bir tereddüt bile etmeden kocasını öldürür. Martin (2004)'e göre Winnie’nin bu eylemi eserde -Stevie'nin ölümü de dâhil- en yıkıcı eylemdir. Ancak bu eylem Winnie'nin güçlü bir kadın oluşundan değil, tam tersi zayıf oluşundan kaynaklanmaktadır. Zira kocasının ölümüyle hayatında ilk kez eline geçen özgürlük fırsatını kullanamaz ve intihar eder.

Winnie Verloc ile Ossipon arasındaki ilişki, Winnie Verloc'un ilişkilerinin temelinde yatan şeyin -maddi ya da manevi- çıkar olduğunun bir göstergesidir. Bu ilişki her ne kadar Bay Verloc'un ölümünden sonra başlasa da, Winnie'nin Ossipon'a bir ilgisinin olduğu daha önceden anlaşılır, çünkü Bay Verloc'un arkadaşları olan Karl Yundt ve Michealis' karşı duygularını açıkça söylemekten çekinmezken, Ossipon'a karşı her zaman temkinlidir.
"Bayan Verloc büyük bir kararlllıkla, Karl Yundt'un "iğrenç bir ihtiyar" olduğunu söyledi. Micheali'e sevgisinin açıkça dile getirdi. Ancak var- lığından daima tedirgin olup soğuk ve mesafeli davrandiğı güçlü kuvvetli Ossipon hakkındaysa hiçbir şey söylemedi. Ve yıllardır bir sıkıntı ve endişe kaynağı olan kardeşi hakkında konuşmaya devam etti" (Conrad, 2006, 74).

Alıntıda da açık olduğu gibi, Winnie Verloc Ossipon'dan uzak durma niyetindedir. Winnie Verloc'un Ossipon'a karşı tedirgin ve mesafeli olmasının nedeni ise, ondan hoşlanmaması değildir. Bunun aksine ondan etkilendiği için Winnie uzak durmaya çalışır; çünkü Ossipon Winnie'nin kardeşi Stevie'ye güvenlik ve rahat sağlayan evliliğine karşı bir "tehdit” oluşturur. Ancak Winnie Verloc'un Ossipon'la ilgili gerçek fikirleri sonradan ortaya çıkmaya başlar. Kocasının arkadaşları hakkında yine yorum yaparken, Ossipon'a karşı yine soğuk ve mesafeli davranır; ama içindeki duyguları bu kez açık eder.

"Ters bir şekilde, tezgâhın arkasını siper alarak, donuk bir yüzle ve soğuk bir bakışla karşıladı̆̆ Ossipon Yoldaş hakkındaysa hiçbir şey söylemedi çünkü o güçlü kuvvetli anarşistle ilgili düşüncelerinin en belirgin yant, klsa bir suskunlukla birlikte, yüzünün mümkün olduğunca en hafif tarafindan kizarmasiydl" (Conrad, 2006, 200).

Yukarıdaki alıntıdan da anlaşılacağı üzere Winnie Verloc Ossipon'dan etkilenmiştir ancak evli olduğu için ondan sürekli uzak durmaya çalışmaktadır. Ossipon da, Winnie Verloc gibi duygu- 
larını sürekli bastırır ve Winnie'ye karşı mesafeli davranır. Ancak Bay Verloc'un ölümünden sonra Winnie’ye şöyle der: “Ben sizi ilk gördüğ̈̈m andan beri sözle anlatılamayacak bir şekilde çok seviyorum. Bunu gizleyemezdim. Öylesine sizinle doluydum ki. Beni bağışlayın, sizin de bunu benim gözlerimden fark etmeniz kaçınılmazdı" (Conrad, 2006, 284).

Kocasını öldürdükten sonra panik içinde dükkândan çıkan Winnie'nin Ossipon'la karşılaşması onun için büyük bir firsattır. Winnie Verloc, Bay Verloc'u öldürdükten sonra kendisini özgür hisseder; çünkü evliliğinin nedeni olan Stevie ve evlendiği adam olan Bay Verloc ölmüşlerdir. Dolayısıyla da Winnie artık hiç kimseye bağlı olmayan "özgür" bir kadındır kendisine göre. Ancak bu özgürlük duygusu bir süre sonra kaybolur; çünkü bir cinayet işlemiştir ve bunun cezası da darağacıdır. Harrington (2004)'e göre ise, Conrad romanın başından beri Winnie ile çizdiği kadın portresiyle Viktorya Dönemi'ndeki toplumsal kısıtlamalar ve sınırlar içinde “özgür kadın”ın var olamayacağını göstermektedir.

"Hiçbir zaman hiçbir şeyin içine derinlemesine bakmayan Bayan Verloc
bunun en derinine bakmak zorunda hissetti kendini. Kadının orada gör-
dügü şey ne hortlak gibi bir surat ne kınayan bir siluet ne vicdan azabı
veren bir görüntü ne de ideal kavraylşla ilgili bir şeydi. Orada bir nesne
gördü. Bu nesne, darağacıyd. Bayan Verloc darağacından korkuyordu”"
(Conrad, 2006, 286).

Winnie Verloc hem artık yalnız bir kadın olduğu için hem de işlediği suçtan ötürü panik içindedir. Ossipon ise ona yardım edebilecek tek kişidir. Winnie'nin Ossipon'la yakınlaşmasının nedeni de Ossipon'un ona karşı olan duygularından dolayı ona yardım edebileceğini düşünmesidir. "Bay Verloc'un dul eşi için bu güçlü kuvvetli adam bir hayat müjdecisiydi” (Conrad, 2006, 292). Bu cümleden de anlaşılacağ 1 gibi Winnie Verloc'un Ossipon'la ilişkisinin temellinde, tıpkı evliliğinde olduğu gibi, bir çıkar amacı vardır.

Martin (2004)'e göre ise, bu durumda Winnie'nin hem çıkar amacının yanı sıra kadının mozaşist eğiliminin de payı vardır. Winnie uzun yıllar süren hapis gibi bir evlilikten kurtulup kendisini asla umursamayacak olan ve yanında asla bir birey olamayacağı başka bir adama, sadece kendisini sevdirebilmek için bir başka hapis hayatına geçmeye çalışarak mazoşist bir tavır sergiler. Bunun nedeni, Winnie'nin mazoşist yanının sürekli olarak babası, kocası ve Ossipon gibi kendisini umursamayan, aşağılayan ve ona ihanet eden adamları tercih etmesidir.

Winnie Verloc, Bay Verloc’u öldürdüğünü Ossipon'a söylemez; fakat Ossipon Bay Verloc’un öldüğünü ya da kaçtığını sandığı için Winnie'yle aralarında bir ilişki başlamasında bir sakınca görmez. Bay Verloc'tan kalan paraları almak için dükkâna döndüklerinde Ossipon kanepede bıçaklanmış yatan Bay Verloc'u görür ve onu Winnie'nin öldürdüğünü anlar. Ardından da Bay Verloc'un cinayetinde suç ortağı olmaktan çekinir ve Winnie'den korkmaya başlar. Winnie'yle birlikte dükkândan çıkıp yurtdışına kaçmak için tren istasyonuna giderler. Winnie'den kocasından kalan paraları bilet alma bahanesiyle alır. Ancak paraları geri vermez ve trene bindikten sonra, tren yavaşça hızlanırken Ossipon vagondan atlayarak kaçar ve kadını tek başına bırakır. Hem yalnız hem de parasız kalan Winnie Paris'e giden gemiden atlayarak intihar eder.

Ossipon'nun da Winnie'yle birlikte olmasının nedeni sadece kadına karşı beslediği duygular değildir. Ossipon Bay Verloc'tan kalan tasarruf paralarının da peşindedir. Ancak cinayete suç ortaklığı gibi bir tehlikeyle karşı karşıya kalmayı göze alamaz. Ossipon, Winnie'nin Bay Verloc'u öldürdüğünü öğrendikten sonra Winnie'ye başka bir gözle bakmaya başlar. Anarşist çevrede lakabı 'Doktor' olan Ossipon bilimselliğe inanan bir insandır. Ayrıca ünlü İtalyan kriminolog Lomroso'nun kitaplarından çok etkilenmiş biridir. Lombroso insanların diş görünüşlerine ve fiziksel özelliklerine bakılarak insanların hangi tip suçları işleyebileceklerinin tespit edileceğine inanır. Ondan çok etkilenen Ossipon, kocasını öldürdüğünü öğrendikten sonra Winnie 
Verloc'u da fiziksel olarak incelemeye başlar.

"O bilimseldi ve bilimsel bir gözle bakıyordu yoz bir varlığın ablasına, kendisi de bir yoz bir varlıktı aslında -katil türünde bir yoz bir varlık. Ossipon kendini en kutsal azizine emanet eden bir Italyan köylüsü gibi ona baklyor ve Lombroso'dan yardım istiyordu. Bilimsel bir gözle baktı kadına. Yanaklarına, burnuna, gözlerine, kulaklarına baktı. Kötü! Öldürücü! Bayan Verloc'un, onun büyük bir tutkuyla ve dikkatle bakışı karşısinda biraz gevşeyen soluk dudakları aralaninca dişlerine de baktı... Hiçbir kuşku yok artık... Bir katil tipi... Ossipon Yoldaş dehşet içindeki ruhunu Lombroso'ya emanet etmeseydi, sirf bilimsel nedenlerden ötürü, ruh diye bir şey taşıdığına inanamazdl” (Conrad, 2006, 316).

Ossipon'un Winnie'yi fiziksel olarak incelemesinin nedeni daha önceden kardeşi Stevie'yi de dükkânda incelemesi ve ona da "yoz" tanısını koyarak çocuğun suça doğuştan meyilli biri olduğunu Bay Verloc'a söylemesiydi. Bu incelemenin ardından kardeşiyle benzer fiziksel özellikler taşıdığı için Winnie'yi “katil türünde bir yoz” olarak görür (Nohrnberg, 2002). Zaten Winnie’yi terk etmesinin nedeni kendisini de öldürebileceğinden korkmasıdır. Lombroso’ya körü körüne inandığı için Winnie'nin intiharının temelinde bu "yozlaşmışlıktan" kaynaklanan deliliğin yattığına inanır (Kim, 2003). Ama Ossipon'un Winnie Verloc'ta gördüğü “yozlaşmışlık”, Winnie'nin karanlıkta kalmış baskı altındaki kişiliğinden ve bu kişiliği kesin olarak çözümlediğini düşünmesinden çok, Ossipon'un saplantılı hayal gücünün bir ürünüdür (Lutz, 2008). Parasını çalıp yarı yolda bıraktığı kadının intihar edip ölmesine neden olan biri olarak görmek yerine kendisini basit bir hırsız olarak görür (Kim, 2003). Aslında bu durum Ossipon'un ahlaki yönden bir "yoz" olduğunun bir göstergesidir (Gilmore, 1969). Oysa Ossipon Lombroso'yu tamamen yanlış yorumlamış ya da kendisine göre çarpıtmıştır. Lomrosso'ya göre kadınların doğuştan meyilli oldukları tek suç fuhuştur ve kadınları diğer suçlara iten şey ya tutku ya da olaylardır; çünkü kadınlar var olan kurallara oldukça bağlı bir şekilde uymayı severler (Lombrosso, 1980; Godfrey, Ferall, \& Karstedt, 2005). Bay Verloc'un ölümüne neden olan şey de Winnie'nin oğlu gibi sevdiği Stevie'ye karşı içinde duyduğu annelik tutkusunun intikam tutkusuna dönüşmesidir (Harrington, 2004).

Winnie Verloc'u intihara sürükleyen neden ise hayatına giren erkeklerin ona ihanet etmeleridir. Harrington (2004)'e göre Conrad, eserinde kadın karakteri hikâyenin ortasına yerleştirip karşılaştığı ihanetler sonucunda, karakteri zihinsel ve ahlaksal bir bozulmanın içine sürüklüyor. Winnie önce babasının ihanetine uğrar çünkü adam onu bir "cadı", kardeşini de bir "ebleh” olarak görür.

"Tüm bu şiddet sahneleri, babalık onuru yaralı bir adamdan gelen korkunç bağırış çağırışların yarattığı kaba gürültülerle birlikte geçip gidiyordu; adam kendini açıç̧a lanetlenmiş saylyordu, çünkü çocuklarından biri "ağzından salyalar çılkan bir ebleh", diğeri ise "baş belası bir cadı" ydl. Kendisi için söylenmişti bu söz Winnie’ye yillar önce” (Conrad, 2006, 261).

İkinci ihanet ise çok sevdiği kardeşinin parçalanarak ölmesine neden olan kocası Bay Verloc’tan gelir; üçüncüsü ise evliyken bile hoşlandığı ve kurtarıcı olarak gördüğü Ossipon'dan. Winnie Verloc'un annesi eskiden bir pansiyon işleten, yaşlı ve sakat bir kadındır. Tek düşüncesiyse oğlu Stevie'dir. Kadın Winnie'yi ve onun duygularını pek fazla düşünmez. Hatta Winnie'nin evlenip evden gitmesinden ve oğluyla yalnız kalmaktan korkar. "Winnie Bay Verloc'la nişanlandı̆̆ını söylediği zaman, annesi içini çekip bulaşık yıkama yerine bakarak, ne olacak şimdi bu Stephen'ın hali, diye düşündü ister istemez" (Conrad, 2006). Winnie Bay Verloc'la evlenince de tedirgin olur kadın; ama adam oğlunu, kadını ve onun mobilyalarını alarak kendi evine götü- 
rünce buna çok memnun olur.

\begin{abstract}
"Evlenen çift kadinı mobilyalariyla birlikte devraldı. Öte yandan kadın maddi sorunlardan tamamen kurtuldu. Damadının gayet iyi tabiatı kadına mutlak bir güven duygusu vermişti. Kizının geleceğinin güvenceye kavuştuğu belliydi ve hatta oğlu Stevie için bile endişelenmesine gerek yoktu. O çocuğun, o zavallı Stevie'nin çok ağır bir yük olduğunu kendisi de kabul ediyordu vaktiyle. Ama Winnie'nin zaylf yaradılışl kardeşine düskünlü̈̆̈̈ ve Bay Verloc'un kibar ve cömert tabiatı sayesinde, zavallı çocuğun bu acımasız dünyada güvende olduğunu hissediyordu. Belki de Verloc'ların çocuğunun olmaması ona pek bir üzüntü vermiyordu" (Conrad, 2006, 22).
\end{abstract}

Fakat daha sonra kadında bir güvensizlik ve yük olma duygusu belirmeye başlar. Bay Verloc'un hem kendisinin hem de oğlu Stevie'nin varlığından rahatsız olmaya başladığını düşünür. “Winnie'nin evliliğinin ardından gelen ilk güvenlik hissi zamanla yok olup gitmişti. Çünkü hiçbir şey kalıcı değildir" (Conrad, 2006, 179). Kadın Bay Verloc'a daha fazla yük olmamak ve adamın kalan tüm sabrını Stevie'ye harcaması için evden ayrılır ve bir bakımevine taşınmaya karar verir. Annesi her ne kadar Winnie'nin birinci önceliği değilse de, onun gidişine içerler, çünkü bu durumun onu evden kendileri kovmuş gibi anlaşılacağından korkar.

Winnie annesini pek fazla önemsemez. Annesi evden gittikten sonra onu biraz özlese de, esas düşündüğü annesine bu kadar alışkın olan Stevie'nin onun yokluğuna nasıl uyum sağlayacağıdır. Kocasına "İlk birkaç günde bu çocuğa moral vermek için ne yapmam gerek hiç bilmiyorum inan ki. Annesinin kendisinden uzak oluşuna alışıncaya kadar sabahtan akşama kadar içi içini yiyecek onun" diyerek bu endişelerini açıkça dile getirir (Conrad, 2006, 196). Zaten Winnie Verloc'un, annesinin gitmesine sinirlenmesinin nedeni, kadının o yaşlı ve sakat haliyle ona çok alışmış ve bakıma muhtaç kardeşi Stevie'yi bırakmasıdır; çünkü annesi Winnie'ye gidişinin gerçek sebebini söylemez.

Stevie'nin ölümünden sonra da bu haberi annesine nasıl ve ne zaman söyleyeceğini hiç düşünmez. Sadece kardeşinin ölümüne çok üzülür. Bay Verloc'u öldürmeden hemen önce kapıya doğru yöneldiğinde Bay Verloc, kadının annesinin yanına gitmek istediğini ve ona Stevie'nin ölüm haberini vermek istediğini düşünür ve şöyle der: "Saat sekizi yirmi beş geçiyor Winnie. Oraya bu kadar geç bir vakitte gitmenin anlamı yok. Bu gece geri dönmen olanaksız. Sen oraya varmadan annen yatmış olacak. Böyle bir haber biraz bekleyebilir" (Conrad, 2006). Oysa ki Winnie'nin aklından bile geçmez annesine gitmek.

Winnie Verloc'un, Bay Verloc'la evlenmesinin en büyük nedeni de Bay Verloc'un Stevie’ye sağlayacağı güvendir. Stevie ne bir işte çalışabilecek durumdadır ne de tek başına dişarıya çıkabilecek bir durumdadır. Bu nedenle de sürekli bir bakıma ve ilgiye ihtiyacı vardır. Stevie özel durumundan dolayı ablası ve annesi tarafından her zaman özel bir muamele görmüştür ve her zaman ona öncelik tanınmıştır.

Winnie'nin annesi Stevie'nin neredeyse tüm sorumluluğunu ve ihtiyaçlarını giderir. Bu durum aslında Stevie'nin küçüklüğünden beri böyle devam etmektedir. Kardeşi doğduğundan beri Winnie her zaman için onun koruyucusu durumundadır (Karl, 1997). Stevie onu bir "ebleh" olarak gören babasından korktuğu zamanlar hemen ablasının yanına gider. "Küçükken, babası doğal bir öfke sonucu bă̆ırdı̆̆ zamanlar, kendini korumak için daima ablası Winnie’nin kısa eteklerinin arkasına saklanırdı" (Conrad, 2006, 23). Gece korktuğu zamanlarda da her zaman ablası onu teselli eder.

"Stevie çocukken korkmuş, üzgün, incinmiş ve ruhunun kara, kapkara sefaletiyle perişan bir halde, karanlı bir köşeye sindiğinde hep ablası 
Winnie gelir, onu teselli verici, huzurla dolu cennete götürür gibi kendi yatağına götürürdü Stevie'de, adı ve adresi gibi önemsiz şeyleri unutmaya yatkın olsa da duygulara karşı korkunç bir bellek vardl. Şefkatle. Yatağa alınmak muhteşem bir ilaçtı" (Conrad, 2006, 185).

Bay Verloc ise Stevie'yi tam anlamıla etkisiz bir eleman olarak görmektedir. Aslında Stevie'yi umursamayan Bay Verloc sadece karısının kardeşi olması nedeniyle ona karşı yüzeysel bir yakınlık hisseder. Annesine göre ise bu yakınlık tamamen yüzeysel bir tahammülden ibarettir. Ancak Winnie içten içe kocasının ve kardeşinin daha çok yakınlaşmasını umar.

“Bay Verloc’un Stevie’ye verdiği değer, hayvanlara pek düşkün olmayan bir adamın, karısının çok sevdiği bir kediye göstereceği kadardı ve bu değer, taşıdı̆̆ iyi niyet ve üstünkörülük yönünden esasen aynı nitelikteydi. İki kadın da bundan fazlasını beklememişlerdi" (Conrad, 2006, 53).

Bay Verloc'un bu üstünkörü ilgisinin farkında olan Winnie ve annesi de Stevie'nin Bay Verloc'u kızdırabilecek herhangi bir şey yapmaması için ellerinden geleni yaparlar. "Onun kendisini evin efendisinin gözünde herhangi bir şekilde sevimsiz hale getirmesini önlemek için harcadıklar çabanın bu iki kadının yaşamına kattığı gerginlik hiç de az değildi” (Conrad, 2006). Winnie'nin annesinin evden ayrılıp bir bakımevine yerleşmeyi kafasına koymasının altında yatan neden de Bay Verloc'un Stevie'ye ve kendisine karşı duyduğu anlayışın zamanla yok olmasından korkması ve bu yüzden hiç değilse "bir yük"ün evden ayrılmasıdır. Böylece Bay Verloc tüm anlayışını Stevie için kullanabilecektir.

"Bay Verloc'un şefkatinin kalıcı olma ihtimali ne kadar az zorlanirsa o kadar artacağı yolundaki katı ve mantıklı görüşü benimsedi. Bu harika adam karısını seviyordu tabii ki, fakat onun akrabalarının, karısına karşı duyduğu sevgiyi gerektiğince göstermesine yetecek kadarına bakmayı yeğleyeceği kuşkusuzdu. Bu duygunun sağlayacă̆ yararın tamamının zavall Stevie'de toplanmast daha iyi olacaktı" (Conrad, 2006, 179).

Winnie'nin kardeşinin Stevie'ye düşkünlüğü Winnie'nin hem hayatında hem de aldığı kararlarda son derece önemli bir etkisi vardır. Winnie'nin evliliğinin yarısını Stevie ve onun güvenliği, diğer yarısını da Winnie'nin Bay Verloc' duyduğu güven oluşturmaktadır (Lutz, 2008). Stevie, Bay Verloc yüzünden ölünce de evliliği oluşturan unsurlar ortadan kalkar. Bu evliliğin bittiğini anlayan Winnie Verloc da oğlu gibi gördüğü kardeşine duyduğu sevgiden dolayı, onu bilerek öldürdüğünü düşündüğü kocası Bay Verloc’u öldürür.

Aslında Winnie Verloc kardeşini çok sevdiği halde onun yokluğunun ne anlama geleceğini bilmez. "Onun yokluğuna katlanamazmışım ha!" dedi Bayan Verloc ağır ağır. "Onun yararına da olsa onun yokluğuna katlanamazmışım ben! Lafa bak! Elbette onun yokluğuna katlanabilirim” (Conrad, 2006, 206). Böyle düşünmesine rağmen Stevie'nin ölüm haberinin ardından müthiş bir üzüntü ve yıkıntı duyan Winnie Verloc Ossipon'la ülke dışına çıkmakla ilgili konuşmalar başlayınca Stevie'nin ölüğünü bir an unutur ve Stevie'nin yolculuklara dayanamayacağını düşünür. Ancak kardeşinin öldügünü hatırlayınca da bu kayba alışmanın çok zor olacağını anlar.

\section{Sonuç}

Bu çalışmada Joseph Conrad'ın Gizli Ajan romanındaki baş kadın karakter olan Winnie Verloc'un bir incelemesi sunulmuştur. İnceleme Winnie Verloc'un, kocası Bay Verloc, kardeşi Stevie, aşığ 1 ve kocasının arkadaşı olan Ossipon ile olan ilişkileri üzerinden gerçekleştirilmiştir. Kadın kahraman, yitirdiği mutluluğun, kaybettiği kardeşinin ve uğradığı ihanetin intikamını almak için kocasını öldürür. Sevgiden yoksun evliliğiyle, kocasının cinsel ihtiyaçlarını karşılamasıyla, olaylardan aptalcasına memnun olmasıyla, ikiyüzlülügüyle Viktorya Dönemi’nin birçok özellik- 
lerini taşır.

Winnie Verloc zekâ özürlü kardeşine ve annesine sağlayacağı imkânlar için kocasıyla evlenmiş, kocasını sevmeyen, eğitim düzeyi düşük, mutsuz bir kadındır. Verloc çiftinin sevgiden yoksun evlilikleri Viktorya Dönemi’ndeki evliliklerle bezerlik göstermektedir. Ayrıca bu zoraki evliliğin ortaya çıkardığı ikiyüzlülük de Viktorya Dönemi'nde var olan özellikler arasında yer almaktadır. Winnie Verloc hayatında önemli yere sahip erkekler tarafından ihanete uğramış bir kadındır. Bu ihanetler sonucunda da önce sevmediği bir adamla evlenir; sonra katil olur, en sonunda da akli dengesini yitirerek intihar eder. Diğer bir değişle erkek egemenliğindeki bir toplumda erkeklerin eylemlerinin kurbanı olur.

Conrad, Winnie Verloc karakteriyle Viktorya Dönemi'nde sadece kadının yerini değil; aynı zamanda dönemin özelliklerini de yansıtmaktadır. Winnie Verloc karakteri üzerinden dolaylı olarak Viktorya Dönemi'nde kadınların sahip oldukları haklarla ve toplumun kadınlara karşı olan bakışıyla kadınların özgür bir birey olamayacağını belirtir. Ayrıca Winnie Verloc karakteriyle Viktorya Dönemi'nde sadece kadının yerini yansıtırken; eserdeki diğer karakterler, tasvirler ve olaylarla aynı zamanda dönemin özelliklerini de yansıtmaktadır.

\section{KAYNAKÇA}

Ablow, R. (2007). The marriage of minds: Reading sympathy in the Victorian marriage plot. Stanford: Stanford University Press.

Arıkan, A. (2009). Edebiyat öğretiminde göresel araç kullanımı: Kısa öykü örneği. Ondokuz Mayıs Üniversitesi Ĕgitim Fakültesi Dergisi, 27, 1-16. İzmir.

Auerbach, S. (2010). “A right sort of man”: Gender, class identity, and social reform in Late-Victorian Britain. The journal of Policy History, 22(1), 64-94. Cambridge.

Bala, S. (1990). Joseph Conrad's fiction. New Delhi: Intellectual Publishing House.

Berstein, S. (2004). Politics, modernity, and domesticity: The Gothicism of Conrad's The Secret Agent. Clio, 32(3), 285-301. Forth Wayne.

Bradbrook, M. C. (1942). Joseph Conrad: Poland's English genius. United Kingdom: Cambridge University Press.

Bush, J. (2005). Special strengths for their own special duties: Women, higher education and gender conservatism in late Victorian Britain. History of Education, 34(4), 387-405.

Christ, C. T., \& Robson, C. (2006). The Victorian Age. Ed. S. Greenblatt, The Norton Anthology of English Literature. Vol. II, 979-1823. USA: Norton Company Press.

Conrad, J. (2006). Gizli ajan. Çev. Süha Sertabiboğlu. Ankara: İmge Yayınevi.

Conrad, J. (1994). The secret agent. London: Penguin Books.

Gilmore, T. B. (1969), Retributive irony in Conrad's The Secret Agent. Conradiana, 1(3), 41-40. Lubbock.

Godfrey, B. S., Farrall, S., \& Karstedt, S. (2005). Explaining gendered sentencing patterns for violent men and women in the Late-Victorian and Edwardian period. The Centre for Crime and Justice Studies, 45, 696-720. London.

Harrington, E. B. (2004). The anarchist's wife: Joseph Conrad's debt to sensation fiction in The Secret Agent. Conradiana, 36(1/2), 51-63. Lubbock.

Karl, F. R. (1997). A reader's guide to Joseph Conrad. USA: Syracuse University Press.

Kim, S. R. (2003). Violence, irony, and laughter: The narration in The Secret Agent, Conradiana, 35(2), 75-97. Lubbock.

Lombroso, C. (1980). The female offender. Littleton, Colorado: Fred Rothman.

Lutz, J. (2008). A rage for order: Fetishism, self-betrayal, and exploitation in The Secret Agent, Conradiana, 40(1), 1-24. Lubbock.

Martin, W. A. (2004). For perverse unreason has its own logical processes: Masochism and redemption in The Secret Agent. Conradiana, 36(1/2), 33-50. Lubbock. 
Meyers, J. (1991). Joseph Conrad a biography. New York; Macmillan Publishing Company.

Nohrnberg, P. (2003). "I wish he'd never been to school": Stevie, newspapers and the reader in The Secret Agent. Conradiana, 35(1/2), 49-61. Lubbock.

Parlaky1ldız, N. A. (2007). Osman Aysu'nun “Odak Noktası" ile Joseph Conrad'ın “Gizli Ajan” romanlarında ana figürlerin şiddet karşısındaki tutumlarının sosyolojik ve psikolojik açıdan analitik olarak karşılaştırılması. (Yayınlanmamış Yüksek Lisans Tezi). Osmangazi Üniversitesi, Eskişehir.

Sikorska, L. (2007). A short history of English Literature. Poznan: Wydawnictwo Poznanskie Publication,

Stott, R. (1993). The woman in black: Race and gender in The Secret Agent. Conradiana, 17(2), 39-58. Lubbock.

Tabili, L. (2002). Poor women's lives: Gender, work, and poverty in Late-Victorian London. Victorian Studies, 44(2), 339-341. Bloomington.

Thomas, M. (2002). Anarcho-feminism in late Victorian and Edwardian Britain: 1880-1914. Internationaal Instituut voor Sociale Geschiedenis, 47, 1-31.

Urgan, M. (2004). Inngiliz Edebiyatı Tarihi. İstanbul: Yapı Kredi Yayınları.

Warner, O. (1950). Joseph Conrad. United Kingdom: Longman \& Green CO.

Watt, I. (2000). The political and social background of The Secret Agent. Ed. I. Watt. Essays on Conrad, 42-64. United Kingdom; Cambridge University Press.

Watts, C. (1993). A preface to Conrad. London: Longman Group U.K. Ltd.

Wheatley, A. E. (2001). A world of their own: Submersion of gender expectations in Conrad's Play. Papers on Language \& Literature, 37(1), 25-50. Edwardsville. 